\title{
Records of harbour porpoise (Phocoena phocoena) in the mouth of the Douro River (northern Portugal) with presence of an anomalous white individual
}

\author{
Ágatha Gil ${ }^{1,2^{*}}$ (D) Ana M. Correia ${ }^{1,2}$ and Isabel Sousa-Pinto ${ }^{1,2}$
}

\begin{abstract}
Background: Harbour porpoise (Phocoena phocoena) is listed under the Annex II of the European Habitats Directive (Directive 92/43/CEE) and Member States are required to designate special areas of conservation to protect their populations. Although harbour porpoise distribution in the Iberian Peninsula has been described, the mouth of the Douro River was never reported as part of its range of distribution.

Methods: Observations from a pier in the mouth of the Douro were carried out to monitor the presence of the harbour porpoises. A monthly measure of sightings per unit of effort was calculated. Information on the sightings, group sizes and records of the white individual is presented.

Results: Twenty six surveys were performed resulting in 22 sightings with group size varying from one to three animals. The white individual was sighted 12 times and recorded both in photographs and video. July was the month with the lowest number of sightings per unit of effort (SPUE), while October had the highest SPUE.

Conclusions: Evidences, such as the presence of an easily recognizable white individual and the reports from local sea-users suggest a degree of site fidelity from this group of harbour porpoises in the mouth of the Douro River. However, further studies are needed to support the effective management and conservation of this group.
\end{abstract}

Keywords: Harbour porpoise, Phocoena phocoena, White individual, Leucistic, Douro River, Northern Portugal

\section{Background}

The harbour porpoise (Phocoena phocoena) is the smallest cetacean in the northwest European continental shelf waters with a wide geographic distribution in the northern hemisphere (Andersen 2003). This cetacean is considered a species of concern according to several international organizations and agreements such as: International Union for Conservation of Nature (IUCN)); Agreement on the Conservation of Small Cetaceans of the Baltic and North Seas (ASCOBANS); the Agreement on the Conservation of Cetaceans of the Black Sea, Mediterranean Sea and Contiguous Atlantic Area (ACCOBAMS);

\footnotetext{
* Correspondence: hthagil@gmail.com

'Interdisciplinary Centre of Marine and Environmental Research (CIIMAR.UP), Terminal de Cruzeiros de Leixões, Avenida Norton de Matos S/N, 4450-208 Matosinhos, Portugal

${ }^{2}$ Department of Biology, Faculty of Sciences, University of Porto (FCUP), Rua do Campo Alegre 1021/1055, 4169-007 Porto, Portugal
}

International Council for the Exploration of the Sea (ICES); International Whaling Commission (IWC) and is listed under the Annex II of the European Habitats Directive (Directive 92/43/CEE). Therefore, Member States are required to designate Special Areas of Conservation (SAC) to protect their populations. Concerns for the species relate to their coastal distribution overlapping with human activities, hence making them more susceptible to anthropogenic threats, such as: direct and incidental catch, pollution, disturbance of feeding or breeding activities due to underwater noise, depletion of their preys and habitat degradation (Dähne et al. 2013; Donovan and Bjørge 1995; Hammond et al. 2002; Hammond et al. 2013; Read et al. 2006). Specifically, in Portugal, their status is "Vulnerable" under the IUCN Red List of Threatened Species and the distribution in the Iberian Peninsula coastal waters is known (Hammond et al. 2002;

(C) The Author(s). 2019 Open Access This article is distributed under the terms of the Creative Commons Attribution 4.0 International License (http://creativecommons.org/licenses/by/4.0/), which permits unrestricted use, distribution, and 
Hammond et al. 2013) with bycatch being described as the main direct threat (Stenson 2003). However, in this region, outdated and scarce data on human activities and porpoise distribution prevents the proper identification of threats and risk assessment (Sequeira 1996).

On May 28th, 2017, a group of harbour porpoises was spotted in the mouth of the Douro River, in the North of Portugal, during a dedicated boat survey for cetacean monitoring. Since then, dedicated surveys were planned to study the occurrence of the animals in the area. Here, we present the first record of harbour porpoises in the mouth of the Douro River, with the presence of an anomalous white individual.

\section{Methods}

A dedicated monitoring programme running from July to October 2017 was planned, in order to assess the presence of harbour porpoises (Phocoena phocoena) in the mouth of the Douro River. Observations from land at a pier (at the coordinates: $41.14 \mathrm{~N}$; 008.67 W; Fig. 1) were scheduled according to several factors: accessibility to the pier, weather conditions and observers' availability.

Monitoring was performed by one to two trained observers with favorable weather conditions (Beaufort state lower than four). Observers searched for harbour porpoise presence with naked-eyed and occasional scans with the support of binoculars $(7 \times 50 \mathrm{~mm})$ in a range of 180 degrees from the front of the pier. When two observers were present at the same time, the range of view was split in two (90 degrees covered by each observer). Whenever animals were spotted, binoculars were used for a positive identification, and the number of individuals (minimum, maximum numbers and best estimate) as well as data on marine traffic were collected. To avoid possible fatigue of the observers, each one performed a maximum of three consecutive hours of survey effort. Each survey was considered as a day of monitoring with periods of observation ranging from $40 \mathrm{~min}$ to $8 \mathrm{~h}$. A sighting was defined as an encounter with a harbour porpoise or group of harbour porpoises and ended when animals were not observed for a period of five consecutive

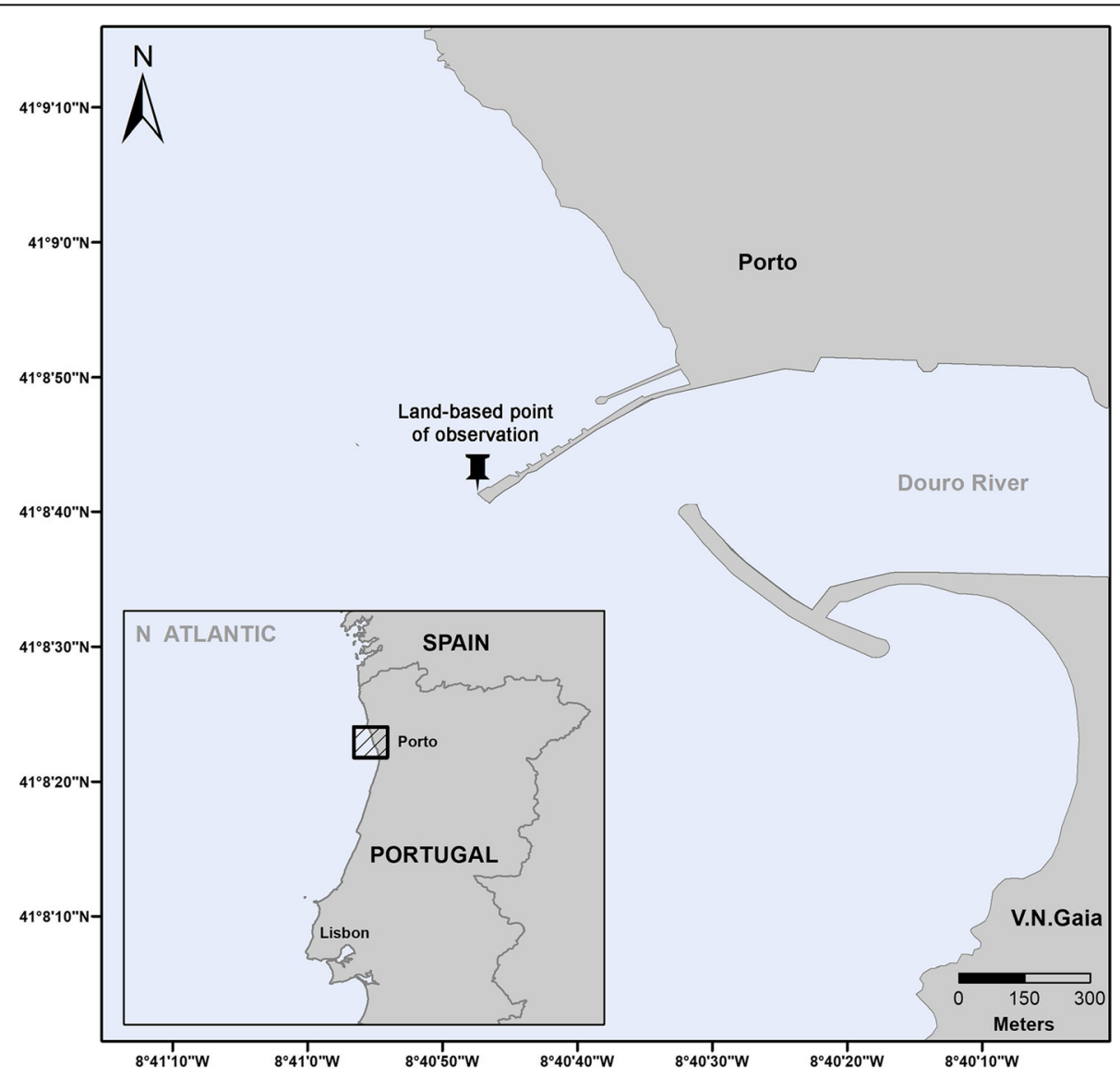

Fig. 1 Monitoring site of the harbour porpoise at the mouth of the Douro River. The land-based point of observation is marked with a pin 
minutes. Since the observation effort was highly heterogeneous between surveys and months, the number of sightings per number of surveys was used as a measure of sightings per unit effort (SPUE) correcting for uneven effort (Elliser and MacIver 2017). The data on survey effort, sightings and SPUE was compiled by month for the duration of the monitoring programme.

\section{Results}

From 26 dedicated surveys we performed a total of $90.87 \mathrm{~h}$ of observation that resulted in 22 sightings. During the monitoring effort, an anomalous white individual was sighted 13 times, 10 of them within the group. The group size ranged from one to three animals: seven sightings of one individual, six of two and nine of three. On five occasions, during the month of October, three animals were spotted. None of them were classified as the white individual, which suggests the group has, at least, four harbour porpoises.

August had the lowest number of surveys and hours of observation, registering no sightings, hence resulting in a SPUE of zero. Besides August, July was the month with the lowest SPUE, but registered the highest number of surveys and hours of observation. The highest number of sightings and SPUE was in October and, after July, this was the month with most hours of observation (Table 1).

The white harbour porpoise has been recorded both in photographs (Fig. 2) and film (see Additional file 1). This individual displays a notch in the dorsal fin and black to grey spots on the dorsal (Fig. 2). Albino cetaceans are characterized by the total absence of melanin. Therefore, this white individual is better characterized as leucistic or hypo-pigmented (Robinson and Haskins 2013; Tonay et al. 2012).

In addition to these effort-based sightings, opportunistic records of the group of harbour porpoises and the white individual from four local sea-users have been reported frequently between 2014 and 2017.

\section{Discussion}

This is the first work reporting on the presence of harbour porpoises in the mouth of the Douro River. Moreover, the group includes an anomalous white individual, which is a rare phenomenon worldwide. Tonay et al. 2012 reported 34 worldwide records of anomalous white harbour porpoises, from which 16 were registered in the Northeast Atlantic Ocean. Some records are of adult animals confirming they can reach adulthood. Although little is known about the leucistic condition, the fact is that the brighter colour makes the individuals more susceptible to predators. The lack of melanin in the skin increases the probability of sunburns and skin cancer and the reduced heat absorption possibly gives lower thermoregulatory capacities in cold waters (Robinson and Haskins 2013). The reported presence of these porpoises and the leucistic individual for at least 3 years, indicates that some of the observed animals are probably adults, surviving in the area despite the anthropogenic impacts.

This group may have a degree of site fidelity as it was systematically seen with the presence of the white individual during dedicated surveys and by locals. Site fidelity for harbour porpoises has been reported (Elliser and MacIver 2017) although lack of previous observations in the area (other than reports from local sea-users) prevent us from drawing such conclusions. Further dedicated surveys during the whole year are recommended to assess whether this is a resident group or if there is a seasonality in its distribution. Moreover, an improved and effective monitoring programme is urgent to understand spatial patterns of distribution of harbour porpoises in the mouth of the Douro River and adjacent areas.

Table 1 Survey effort and sightings of harbour porpoises (Phocoena phocoena) in the mouth of the Douro River

\begin{tabular}{|c|c|c|c|c|c|c|}
\hline $\begin{array}{l}2017 \\
\text { Month }\end{array}$ & $\begin{array}{l}\text { Number of } \\
\text { surveys }\end{array}$ & $\begin{array}{l}\text { Total hours of } \\
\text { observation }\end{array}$ & $\begin{array}{l}\text { Total } \\
\text { Sightings }\end{array}$ & Total SPUE & $\begin{array}{l}\text { Group Size } \\
\text { (min-max; } \\
\text { mean } \pm \text { sd) }\end{array}$ & $\begin{array}{l}\text { Number of } \\
\text { sightings with AWI }\end{array}$ \\
\hline July & 13 & 36.58 & 06 & 0.46 & $\begin{array}{l}2-3 ; \\
2.33 \pm 0.52\end{array}$ & 06 \\
\hline August & 02 & 5.98 & 00 & 0.00 & - & 00 \\
\hline September & 05 & 15.88 & 04 & 0.80 & $\begin{array}{l}1-3 \\
1.75 \pm 0.96\end{array}$ & 03 \\
\hline October & 06 & 32.43 & 12 & 2.00 & $\begin{array}{l}1-3 \\
2.08 \pm 1.00\end{array}$ & 04 \\
\hline Total & 26 & 90.87 & 22 & 0.85 & $\begin{array}{l}1-3 \\
2.09 \pm 0.87\end{array}$ & 13 \\
\hline
\end{tabular}

The table summarises total and monthly data for the surveys between July and October 2017. The measure of sightings per unit of effort (SPUE) is calculated as the total number of sightings per number of surveys; group size is presented with minimum (min), maximum (max), mean and standard deviation (sd) values; and the number of sightings with the presence of the anomalous white individual (AWI) is also compiled 

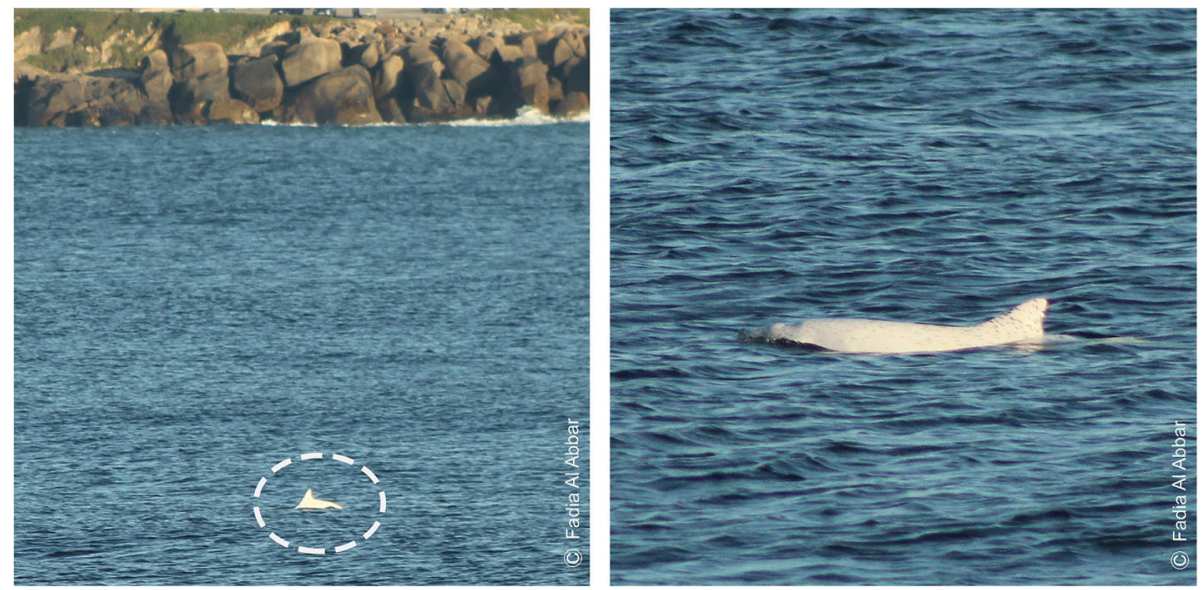

Fig. 2 Anomalous white harbour porpoise sighted at the mouth of the Douro River

\section{Conclusions}

This is the first record of harbour porpoises in the mouth of the Douro River. The results from dedicated surveys and 3 years of reports from local sea-users, strongly suggest this group may have some degree of site fidelity. Moreover, the systematic presence of an easily recognizable individual (anomalous white porpoise) corroborates this hypothesis.

Given the "Vulnerable" state of harbour porpoises in Portugal, dedicated surveys are needed to characterize this group's use of the area and the overlap of its distribution with human activities. Further studies are urgent to effectively manage and protect these harbour porpoises, which is required from the Member States under the European Habitats Directive (Directive 92/43/CEE).

\section{Additional file}

Additional file 1: Anomalous white porpoise (Phocoena phocoena) in the mouth of the Douro River. This data is a video that shows the presence of the reported anomalous white individual (Phocoena phocoena) in the mouth of the Douro River, close to the the land-based point of observation, playing with a prey. (MP4 $20461 \mathrm{~kb}$ )

\section{Abbreviations}

ACCOBAMS: Agreement on the Conservation of Cetaceans of the Black Sea, Mediterranean Sea and Contiguous Atlantic Area; ASCOBANS: Agreement on the Conservation of Small Cetaceans of the Baltic and North Seas; AWI: Anomalous White Individual; ICES: International Council for the Exploration of the Sea; IUCN: International Union for Conservation of Nature; IWC: International Whaling Commission; SAC: Special Area of Conservation; SPUE: Sighting per Unit of Effort

\section{Acknowledgements}

The work was carried out at the Interdisciplinary Centre of Marine and Environmental Research (CIIMAR - Porto, Portugal). Thanks to the monitoring programme, CETUS Project. We are extremely grateful for the contribution and dedication of all the volunteers during the monitoring programme, specifically to Rhiannon Nichol and Mieke Weyn. We acknowledge Samantha Gil, Nicholas Geth, Carolina Mantega and Ingrid Koeck, who reviewed the manuscript thoroughly for correction of English grammar and spelling. We thank the reviewers for their comments and suggestions.

\section{Funding}

This article is a result of the project Marlnfo - Integrated Platform for Marine Data Acquisition and Analysis (reference NORTE-01-0145-FEDER-000031), supported by North Portugal Regional Operational Programme (NORTE 2020), under the PORTUGAL 2020 Partnership Agreement, through the European Regional Development Fund (ERDF).

Availability of data and materials

All data generated or analysed during this study are included in this published article and its supplementary files.

\section{Authors' contributions}

All co-authors were highly involved in the preparation of this manuscript: AG was in charge of data collection, processing, analysis and redaction of the manuscript, AMC was involved in data processing, analysis and redaction of the manuscript, IS-P was the lead supervisor of the work. All co-authors reviewed and approved the manuscript being submitted.

Ethics approval and consent to participate

Not applicable

\section{Consent for publication}

All personal data were consented for publication.

\section{Competing interests}

The authors declare that they have no competing interests.

\section{Publisher's Note}

Springer Nature remains neutral with regard to jurisdictional claims in published maps and institutional affiliations.

Received: 3 May 2018 Accepted: 12 December 2018

Published online: 22 January 2019

\section{References}

Agreement on the Conservation of Cetaceans of the Black Sea, Mediterranean Sea and Contiguous Atlantic Area (ACCOBAMS). http://www.ascobans.org . Accessed 18 Nov 2017.

Agreement on the Conservation of Small Cetaceans of the Baltic and North Seas (ASCOBANS). http://www.ascobans.org. Accessed 18 Nov 2017.

Andersen LW. Harbour porpoises (Phocoena phocoena) in the North Atlantic: distribution and genetic population structure. NAMMCO Sci Publ. 2003;5:11-30. https://doi.org/10.7557/3.2737.

Dähne M, Gilles A, Lucke K, Peschko V, Adler S, Krügel K, et al. Effects of piledriving on harbour porpoises (Phocoena phocoena) at the first offshore wind farm in Germany. Environ Res Lett. 2013;8:025002. https://doi.org/10.1088/ 1748-9326/8/2/025002. 
Donovan GP, Bjørge A. Harbour porpoises in the North Atlantic. Rep Int Whaling Comm. 1995;16:3-25.

Elliser CR, Maclver KH. Group characteristics, site fidelity, and photo-identification of harbor porpoises, Phocoena phocoena, in burrows pass, Fidalgo Island, Washington. Mar Mammal Sci. 2017. https://doi.org/10.1111/mms.12459.

Hammond PS, Berggren P, Benke H, Borchers DL, Collet A, Heide-Jørgensen MP, et al. Abundance of harbour porpoise and other cetaceans in the North Sea and adjacent waters. J Appl Ecol. 2002;39(2):361-76. https://doi.org/10.1046/j. 1365-2664.2002.00713.x

Hammond PS, Macleod K, Berggren P, Borchers DL, Burt ML, Cañadas A, et al. Cetacean abundance and distribution in European Atlantic shelf waters to inform conservation and management. Biol Conserv. 2013;164:107-22. https://doi.org/10.1016/j.biocon.2013.04.010.

International Council for the Exploration of the Sea (ICES). http://www.ices.dk ). Accessed 18 Nov 2017.

International Union for Conservation of Nature (IUCN)). [1] http://www.iucn.org. Accessed 18 Nov 2017.

International Whaling Commission (IWC). [5] https://iwc.int . Accessed 18 Nov 2017.

IUCN Red List of Threatened Species. [6] http://www.icnf.pt. Accessed 18 Nov 2017.

Read AJ, Drinker P, Northridge S. Bycatch of marine mammals in U.S. and global fisheries. Conserv Biol. 2006;20(1):163-9.

Robinson KP, Haskins GN. Rare sighting of an anomalously white harbour porpoise (Phocoena phocoena) in the Moray firth, north-East Scotland. Mar Biodivers Rec. 2013;6:1-3. https://doi.org/10.1017/S1755267212001339

Sequeira M. Harbour porpoises, Phocoena phocoena, in Portuguese waters. Rep Int Whaling Comm. 1996;46:583-6.

Stenson GB. Harbour porpoise (Phocoena phocoena) in the North Atlantic: Abundance, removals, and sustainability of removals. NAMMCO Sci Publ. 2003;5:271-302. https://doi.org/10.7557/3.2830.

Tonay AM, Bilgin S, Dede A, Akkava A, Yesilcicek T, Kose O, et al. First records of anomalously white harbour porpoises (Phocoena phocoena) in the Turkish seas with a global review. Hystrix. 2012;23(2):76-87. https://doi.org/10.4404/ hystrix-23.2-4792.

Ready to submit your research? Choose BMC and benefit from:

- fast, convenient online submission

- thorough peer review by experienced researchers in your field

- rapid publication on acceptance

- support for research data, including large and complex data types

- gold Open Access which fosters wider collaboration and increased citations

- maximum visibility for your research: over $100 \mathrm{M}$ website views per year

At $\mathrm{BMC}$, research is always in progress.

Learn more biomedcentral.com/submissions 